\title{
Anticarcinogenic Effects of Odorant Substances Citral, Citrathal R and Cyclovertal on Breast Cancer in vitro
}

Anna-Lena Klauser, 'Marc Hirschfeld, ${ }^{1-3}$ Andrea Ritter, 1,2 Gerta Rücker, ${ }^{1,4}$ Markus Jäger, ',2 Julia Gundarova,' Daniela Weiss, ${ }^{1,2}$ Ingolf Juhasz-Böss, ${ }^{1,2}$ Kai Berner, ${ }^{1,2}$ Thalia Erbes, ${ }^{1,2}$ Jasmin Asberger (iD) ${ }^{1,2}$

'Faculty of Medicine, University of Freiburg, Freiburg, Germany; ${ }^{2}$ Department of Obstetrics and Gynecology, Medical Center - University of Freiburg, Freiburg, Germany; ${ }^{3}$ Institute of Veterinary Medicine, University of Göttingen, Göttingen, Germany; ${ }^{4}$ Institute of Medical Biometry and Statistics, Medical Center - University of Freiburg, Freiburg, Germany

Video abstract

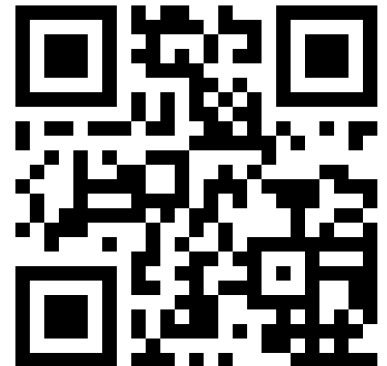

Point your SmartPhone at the code above. If you have a $Q R$ code reader the video abstract will appear. Or use: https://youtu.be/-gpMvmx9sCU

Correspondence: Jasmin Asberger Department of Obstetrics and Gynecology, Faculty of Medicine and Medical Center - University of Freiburg, Hugstetterstr. 55, Freiburg, 79106, Germany

Tel +4976I 27030020

Fax +4976I 27030370

Email jasmin.asberger@uniklinik-freiburg.de
Purpose: In 2020, breast cancer still represents the most common type of cancer in women worldwide. Depending on the specific molecular subtype, clinical breast cancer management comprises surgery, radiotherapy, chemotherapy and targeted therapy. Furthermore, there are some therapeutic approaches from the field of complementary and alternative medicine. Current research focuses on the elucidation of new therapeutic targets for treatment development. Odorant substances affect apoptosis, proliferation and cell cycle in healthy and cancerous cells. Exact signalling pathways involved are not entirely clear. The present study aims to analyse their therapeutic potential in breast cancer.

Methods: This study focuses on the effect of commonly used odorant substances (citral, citrathal R, cyclovertal, para-cymol, hexylacetat, herbavert, dihydromyrcerol and limonen) on the breast cancer cell lines MDA-MB-231, T47-D and BT474. Methodologically, this study applied cell culturing, MTT assay for detection of IC50 of the odorant substance, RNA purification followed by qRT-PCR, protein isolation and Western Blot, as well as immunocytochemistry. Further, this study investigates the role of transient receptor potential channel V1 (TRPV1), involved in the mechanisms of action for some odorant substances. Therefore, capsazepine, a TRPV1 antagonist, was used.

Results: The odorant substances citral, citrathal $\mathrm{R}$ and cyclovertal have significant proapoptotic $(\mathrm{p}<0.001)$, anti-proliferative $(\mathrm{p}<0.001)$ and cell cycle-arresting effects measurable in RNA expression as well as in protein levels and immunocytochemical staining. The combination of citral and capsazepine no longer showed significant pro-apoptotic, antiproliferative, and cell cycle inhibitory effects compared to the compounds alone. This indicates that TRPV1 is necessary for the signal transduction of citral.

Conclusion: This present study reveals three odorant substances with effects on cell viability, indicating their potential use in breast cancer therapy.

Keywords: citral, citrathal R, cyclovertal, odorant substances, olfactory receptor and breast cancer

\section{Introduction}

Breast cancer (BC) is the most common type of cancer affecting women and the leading cause of cancer-related deaths among women worldwide. ${ }^{1}$ Breast tumors are heterogeneous. According to the World Health Organization (WHO) classification, $\mathrm{BC}$ can be categorized by histology. ${ }^{2}$ Depending on the specific molecular subtype, clinical BC management comprises surgery, radiotherapy and chemotherapy. ${ }^{3}$ Targeted therapy is also increasingly used in specific subtypes. ${ }^{4}$ In addition, a number of integrative therapy options are also available. ${ }^{5,6}$ However, 
increasing cancer morbidity demands further research and the development of novel therapeutic approaches.

Olfactory receptors (ORs) detect volatile odor molecules in the environment. In 1992, Parmentier et al first detected ORs outside the nose, called ectopic ORs. ${ }^{7}$ So far, ORs have already been detected in various ectopic tissues, including breast, colon and liver tissue. ${ }^{8}$ The biological functions of ectopic ORs are varied. In particular, they have a regulatory influence on processes, such as sperm chemotaxis, wound healing and cancer cell inhibition. ${ }^{9-11}$ Ectopic ORs are G protein-coupled receptors (GPCRs) activating the Ras/Raf/MAPK pathway and thereby induce specific transcription factors. ${ }^{12}$ However, other receptors and transport protein channels, like transient receptor potential channels (TRP) or voltage gated L-type calcium channels, might also be involved in the signal transduction of volatile molecules. ${ }^{13-15}$ TRP channels are well-studied cation channels, which can be activated by a vast number of stimuli. ${ }^{16}$ It has also been demonstrated that these cation channels influence cancer growth rates. The odorant substance citral activates TRP channels in dorsal root ganglion cells, raising the question of whether odorant substances might also have effects without activating the olfactory receptors at all. ${ }^{17}$ These findings suggest that ORs may be a significant target for future cancer therapy, particularly since $G$ protein-coupled receptors already serve as common therapeutic targets. ${ }^{18}$

In breast tissue, ORs and TRP channels were both expressed and may have an influence on breast carcinogenesis. OR expression differs between healthy and malignant breast tissue. For example, OR2B6 expresses in carcinoma tissue only, qualifying it as a BC biomarker. ${ }^{19}$ The study by Masjedi et al suggests that specific OR genes may be correlated with BC characteristics. Therefore, ORs could be potential markers for new diagnostic means and/ or therapy. ${ }^{20}$ Likewise, TRP channel expression differs between various breast tissues. On the one hand, TRPM8 was not found in healthy breast tissue; on the other hand, TRPV1 and TRPM7 seem to be expressed in any kind of breast tissue. $^{21}$ In MCF-7 cells, silencing of TRPM7, the essential TRP channel for calcium homeostasis reduces cell growth. ${ }^{22}$ Activation of TRPV1 with the agonist capsaicin can induce anti-proliferative and pro-apoptotic effects. Therefore, TRPV1 has been described as one potential target for cancer therapy. ${ }^{23}$

The present study aims to identify the effect on BC cell growth and viability of the eight odorants para-cymol, citral, hexylacetat, herbavert, dihydromyrcerol, limonen, citrathal
$\mathrm{R}$ and cyclovertal, which are frequently used in perfumes and cosmetics. The influence was analysed using in vitro BC models. Well-known cellular markers (Table 1) were used to identify the effects of the odorant substances. Ki67 and PCNA (Proliferating Cell Nuclear Antigen) were used as proliferation markers. $^{24,25}$ p53, SIRT1 (sirtuin-1), Survivin and Annexin $\mathrm{V}$ were used as markers for apoptosis. ${ }^{26-29}$ The cyclins A2, D1 and E1 and the protein TPX2 (Targeting protein for Xklp2) served as cell cycle markers. ${ }^{30,31}$ Various cellular pathways play an important role in cancer. In order to identify a possibly involved signaling pathway, the signaling pathway markers ERK1/2 (extracellular signal-regulated kinases 1/2), p38 MAPK (p38 mitogen-activated kinase) and STK24 (serine/

Table I Cellular Markers and Their Reported Function

\begin{tabular}{|c|c|c|}
\hline Cellular Markers & Reported Function & References \\
\hline Ki 67 & Proliferation marker & [24] \\
\hline PCNA & $\begin{array}{l}\text { Various effects on replication, cell } \\
\text { cycle and repair mechanisms. }\end{array}$ & {$[25]$} \\
\hline p53 & $\begin{array}{l}\text { p53 induces apoptosis by activating } \\
\text { pro-apoptotic proteins }\end{array}$ & [26] \\
\hline SIRTI (sirtuin-I) & $\begin{array}{l}\text { Anti-apoptotic effect by inactivation } \\
\text { of p53 }\end{array}$ & [27] \\
\hline Survivin & $\begin{array}{l}\text { Anti-apoptotic by inhibiting caspase- } \\
9 \text { and further regulates mitotic } \\
\text { spindle checkpoints }\end{array}$ & [28] \\
\hline Annexin V & $\begin{array}{l}\text { Binds the externalised phospholipids } \\
\text { on the outer cell membrane during } \\
\text { apoptosis. }\end{array}$ & [29] \\
\hline Cyclins A2, DI and EI & $\begin{array}{l}\text { Activating proteins at cell cycle } \\
\text { checkpoints. Elevated levels of cyclin } \\
\text { DI were also shown to increase } \\
\text { invasion capability of breast cancer } \\
\text { cell lines. }\end{array}$ & {$[30]$} \\
\hline $\begin{array}{l}\text { TPX2 (Targeting } \\
\text { protein for Xklp2) }\end{array}$ & $\begin{array}{l}\text { Necessary for spindle function and } \\
\text { chromosome segregation during } \\
\text { mitosis. Its overexpression is } \\
\text { associated with tumor growth. }\end{array}$ & {$[31]$} \\
\hline $\begin{array}{l}\text { ERKI/2 (extracellular } \\
\text { signal-regulated } \\
\text { kinases } 1 / 2 \text { ) }\end{array}$ & $\begin{array}{l}\text { Function in the pro-cancerous and } \\
\text { pro-proliferative Ras/Raf-pathway. }\end{array}$ & [32] \\
\hline $\begin{array}{l}\text { p38 MAPK (p38 } \\
\text { mitogen-activated } \\
\text { kinase) }\end{array}$ & $\begin{array}{l}\text { Associated with Ras/Raf-pathway; } \\
\text { transmits mostly inflammatory and } \\
\text { apoptotic signals. }\end{array}$ & [33] \\
\hline $\begin{array}{l}\text { STK24 (Serine/ } \\
\text { Threonine kinase 24) }\end{array}$ & $\begin{array}{l}\text { Higher expressions are associated } \\
\text { with more aggressive breast cancer } \\
\text { subtypes. Associated with the Ras/ } \\
\text { Raf pathway }\end{array}$ & {$[34,35]$} \\
\hline
\end{tabular}


threonine kinase 24) were investigated. ${ }^{32-35}$ Furthermore, this study aimed to understand whether ORs or TRP channels are involved in the potential growth inhibitory effect of the odorant substances in $\mathrm{BC}$ cell lines.

\section{Methods}

\section{Chemicals}

The tested odorant substances para-cymol (CAS: 99-87-6), citral (CAS: 5392-40-5), hexylacetat (CAS: 142-92-7), herbavert (CAS: 67583-77-1), dihydromyrcenol (CAS: 1847958-8), limonene (CAS: 5989-27-5), citrathal R (CAS: 90480-35-6) and cyclovertal (CAS: 67801-65-4) were provided by Henkel (Henkel Fragrance Center; Krefeld, Germany). Names based on the IUPAC nomenclature are supplemented (Table 2). The substances were diluted into dimethyl sulfoxide (DMSO, Honeywell International Inc., Offenbach, Germany). The TRPV1 inhibitor capsazepine was purchased from Abcam (Cambridge, UK).

\section{Cell Culture}

BT474 cells (\#300131) and T-47D cells (\#300353) were purchased from CLS Cell Lines Service $\mathrm{GmbH}$ (Eppelheim, Germany), MDA-MB-231 cells (\#92020424) from Sigma-Aldrich (Taufkirchen, Germany). Cells were recently (01/2019) authenticated by PCR-single-locustechnology by Eurofins Medigenomix Forensik $\mathrm{GmbH}$ (Ebersberg, Germany).

BT474 and MDA-MB-231 were cultivated in Dulbecco's Modified Eagle Medium with F12 nutrient

Table 2 Names of Odorous Substances According to the IUPAC Nomenclature

\begin{tabular}{|l|l|}
\hline Odorant Substance & IUPAC \\
\hline Para-cymol (CAS: 99-87-6) & Para-mentha-I,8(9)-diene \\
\hline Citral (CAS: 5392-40-5) & 3,7-dimethylocta-2,6-dienal \\
\hline Hexylacetate (CAS: 142-92-7) & C8HI6O2 \\
\hline Herbavert (CAS: 67583-77-I) & 3-ethoxy-I, I,5-trimethylcyclohexane \\
\hline $\begin{array}{l}\text { Dihydromyrcenol (CAS: 18479- } \\
\text { 58-8) }\end{array}$ & 2,6-dimethyloct-7-en-2-ol \\
\hline Limonene (CAS: 5989-27-5) & I-methyl-4-prop-1-en-2-ylcyclohexene \\
\hline Citrathal R (CAS: 90480-35-6) & $\begin{array}{l}\text { 2,6-Octadienal, 3,7-dimethyl-, acid- } \\
\text { isomerized }\end{array}$ \\
\hline Cyclovertal (CAS: 6780I-65-4) & $\begin{array}{l}\text { 3,6-dimethylcyclohex-3-ene- } \\
\text { I-carbaldehyde }\end{array}$ \\
\hline
\end{tabular}

solution (DMEM/F12, Gibco, Thermo Fisher Scientific, Waltham, USA) containing 5\% fetal bovine serum (Gibco), 1\% HEPES buffer (Sigma-Aldrich) and 1\% penicillin/streptomycin (Sigma-Aldrich). T-47D cells were cultivated in Roswell Park Memorial Institute Medium (RPMI, Gibco) containing 5\% fetal bovine serum (Gibco), 1\% HEPES buffer (Sigma-Aldrich), 1\% penicillin/streptomycin (Sigma-Aldrich) and $2.5 \mu \mathrm{L} / \mathrm{mL}$ insulin (Sanofi, Frankfurt). All cells were cultured in an incubator with humidified atmosphere $\left(37^{\circ} \mathrm{C}, 5 \% \mathrm{CO}_{2}\right.$ and $95 \%$ air $)$.

\section{Substance Application}

For substance application, cells were passaged and grown in $75 \mathrm{~cm}^{2}$ culture flasks. After a confluence of $80 \%$ was reached the substance was applied, and cells were incubated for 24 hours in a separate incubator. An equimolar amount of DMSO served as control. For inhibition of TRPV1, the equimolar amount of capsazepine was coapplied with the odorant substance and incubated for further 24 hours in a different incubator.

\section{RNA-Isolation, cDNA-Synthesis and Polymerase Chain Reaction (PCR)}

Total RNA isolation was performed according to manufacturer's instructions with TRIzol ${ }^{\circledR}$ Reagent (Thermo Fisher Scientific, Braunschweig, Germany) and chloroform was added to separate the aqueous and organic phase by centrifugation. The aqueous phase contained the RNA, which was further purified using the EURx GeneMatrix UNIVERSAL RNA/miRNA Purification Kit (Roboklon, Berlin, Germany).

Reverse transcription was performed for cDNA synthesis. First, the amount of RNA in each sample was quantified with the NanoPhotometer ${ }^{\circledR}$ N60 (Implen GmbH, Munich, Germany). The Master Mix for reverse transcription contained $5 \mu \mathrm{L}$ 5xM-MLV-RT-buffer (Thermo Fisher Scientific), $1 \mu \mathrm{L} 5 \mathrm{mM}$ dNTP (Jena Bioscience, Jena, Germany), $1 \mu \mathrm{L}$ RT-Primer (Jena Biosience), $0.25 \mu \mathrm{L}$ Maxima RT (200 U/ $\mu \mathrm{L}$, Thermo Fisher Scientific) and 0.25 $\mu \mathrm{L}$ Superasein $(20 \mathrm{U} / \mu \mathrm{L}$, Invitrogen, Life Technologies, Darmstadt, Germany) for each sample. $2 \mu \mathrm{g}$ RNA was added per sample. The RT protocol included timetemperature intervals of $1 \min 65^{\circ} \mathrm{C}, 30 \min 50^{\circ} \mathrm{C}, 10$ min $85^{\circ} \mathrm{C}$ using the Mastercycler nexus gradient (Eppendorf, Wesseling-Berzdorf, Germany). Gene expression was quantified by real-time PCR with a PCR-MasterMix containing $9 \mu \mathrm{L}$ in-house qPCR Mastermix (containing 
TRIS pH8.1, dATP, dCTP, dGTP, dTTP, magnesium, potassium ammonium, SYBRGreen (Jena Bioscience, Jena, Germany), enhancers, HotStart Taq Polymerase (Jena Bioscience)) and $1 \mu \mathrm{L}$ cDNA for each sample. All primer sequences are listed in Table 3 . The PCR protocol included preincubation at $95^{\circ} \mathrm{C}, 40$ cycles of $60^{\circ} \mathrm{C}-95^{\circ} \mathrm{C}-60^{\circ} \mathrm{C}$ and a melting curve from $65^{\circ} \mathrm{C}$ to $95^{\circ} \mathrm{C}$ using the Light Cycler $^{\circledR}$ 480 (Roche, Mannheim, Germany).

Table 3 Primer Sequences

\begin{tabular}{|c|c|}
\hline Primer & Sequence \\
\hline ALASI & $\begin{array}{l}\text { S: } 5^{\circ}-\text { AGC GCA ACG TCA AAC TCA T }-3^{\prime} \\
\text { AS: } 5^{\circ}-\text { TTT TAG CAG CAT CTG CAA CC - }-3^{\prime}\end{array}$ \\
\hline Cyclin A2 & 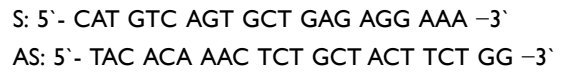 \\
\hline Cyclin DI & 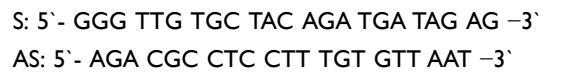 \\
\hline Cyclin EI & 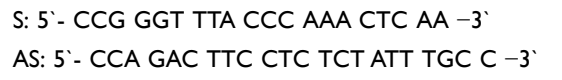 \\
\hline ERKI & $\begin{array}{l}\text { S: } 5^{\prime}-\text { TAC ACG CAG TTG CAG TAC AT }-3^{\prime} \\
\text { AS: } 5^{\prime}-\text { CAG TAG GTC TGA TGT TCG AAG G }-3^{\prime}\end{array}$ \\
\hline ERK2 & $\begin{array}{l}\text { S: } 5^{\prime}-\text { CTA CAC CAA CCT CTC GTA CAT C -3' } \\
\text { AS: 5'- CAG TAG GTC TGG TGC TCA AA -3' }\end{array}$ \\
\hline $\begin{array}{l}\text { ESR } 817 \text { (estrogen } \\
\text { receptor) }\end{array}$ & 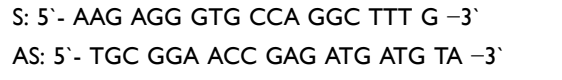 \\
\hline GAPDH & 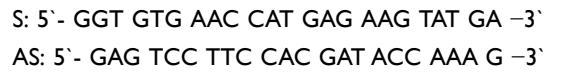 \\
\hline Ki67 & 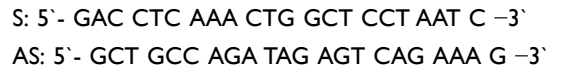 \\
\hline p38 MAP-Kinase & $\begin{array}{l}\text { S: } 5^{\prime}-\text { CAG GAG CTG AAC AAG ACA ATC T -3' } \\
\text { AS: } 5{ }^{\prime}-\text { TCT TCA CTG CCA CAC GTA AC - } 3^{\prime}\end{array}$ \\
\hline p53 & $\begin{array}{l}\text { S: } 5^{\prime}-\mathrm{GTC}^{\prime} \text { TGG GCT TCT TGC ATT CT -3' } \\
\text { AS: } 5^{\prime}-\mathrm{GCA} \text { CAG GGC AGG TCT TG }-3^{\prime}\end{array}$ \\
\hline $\begin{array}{l}\text { PGR (progesterone } \\
\text { receptor) }\end{array}$ & 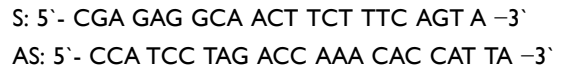 \\
\hline SIRTI & $\begin{array}{l}\text { S: } 5^{\prime}-\text { CCA GAT CCT AAG CGA TGT T }-3^{\prime} \\
\text { AS: } 5^{\prime}-\text { CAG AGA GAT GGC TGG AAT TGT }-3 \text { ' }\end{array}$ \\
\hline STK 24 & 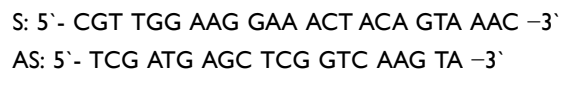 \\
\hline Survivin & $\begin{array}{l}\text { S: } 5^{\prime}-\text { CGA GGC TGG CTT CAT CCA CT -3' } \\
\text { AS: } 5^{\prime}-\text { ACG GCG CAC TTT CTT CGC A - } 3^{\prime}\end{array}$ \\
\hline TBP & 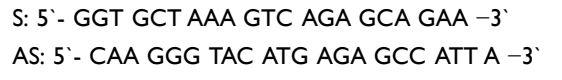 \\
\hline TPX2 & $\begin{array}{l}\text { S: } 5^{\prime}-\text { GGC CTT TCT GGT TCT CTA GTT C }-3^{\prime} \\
\text { AS: } 5^{\prime}-\text { CTT CTA CCT CAG CCA TTC TCT TC -3. }\end{array}$ \\
\hline
\end{tabular}

\section{MTT-Assay}

The MTT-Assay was performed to evaluate the IC50 (quantitative measure that indicates how much of a particular inhibitory substance is needed to inhibit, in vitro, a given biological process or biological component by $50 \%$ ). The cells were seeded at a density of 40,000/mL (BT474 and MDA-MB-231) and 45,000/mL (T-47D) in 24-well plates. At a confluence of $80 \%$, the medium was replaced by a medium containing substance in concentrations of $25 \mu \mathrm{M}, 50 \mu \mathrm{M}, 75 \mu \mathrm{M}, 100 \mu \mathrm{M}$ and $150 \mu \mathrm{M}$. An equal amount of pure DMSO served as control. After incubating for 24 hours in a separate incubator, 10\% MTT (Biomol, Hamburg, Germany, $5 \mathrm{mg} / \mathrm{mL}$ PBS) was dosed to each well. After two hours, the medium was carefully aspirated and $500 \mu \mathrm{L}$ lysis buffer (Isopropanol (Sigma-Aldrich), 1\% Triton-X (SigmaAldrich), 0.1\% $\mathrm{HCl}$ (32\%, Merck, Darmstadt, Germany)) were added to dissolve the formazan crystals. The optical density was measured with the $\mu$ Quant ${ }^{\mathrm{TM}}$ Microplate Spectrophotometer (BioTek Instruments, Inc., Winooski, USA) at $570 \mathrm{~nm}$, and the dose-effect curve was calculated.

\section{Protein Isolation, BCA-Assay and Western Blot}

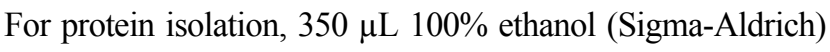
was added to precipitate DNA first. After pelleting the protein with isopropanol, the protein pellet was washed with $70 \%$ ethanol, airdried and protein lysis buffer (1\% SDS (Carl Roth, Karlsruhe, Germany), 1\% Triton X (Sigma-Aldrich), 1 mM ETDA (Serva, Heidelberg, Germany), 0.1 M HEPES buffer (Sigma-Aldrich)) was added to dissolve the pellet again. To quantify the protein concentration, a BCA-assay was performed with the BCA Protein Assay Kit (Thermo Fisher Scientific) according to the manufacturer's protocol. Western Blot technique was performed according to the recommendations of Schagger and von Jagow. ${ }^{36}$ The antibodies, namely $\beta$-Tubulin (sc-55529, dilution 1:1000), PCNA (sc-56, dilution 1:2000), p53 (sc-126, dilution 1:20`000), were all purchased from Santa Cruz Biotechnology, Inc. (Santa Cruz, USA). ERK1/2 (4695, dilution 1:1000) was purchased from Cell Signaling Technology (Frankfurt, Germany) and

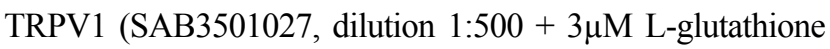
reduced) was purchased from Sigma-Aldrich (St. Louis, USA).

After washing, the membranes were incubated for one hour with peroxidase-conjugated goat anti-mouse IgG secondary antibody (for $\beta$-Tubulin and PCNA, 
dilution 1:5000, for $\mathrm{p} 53$, dilution 1:7500) and peroxidaseconjugated goat anti-rabbit IgG secondary antibody (for ERK 1/2 and TRPV1, dilution 1:5000) in blocking buffer at room temperature $\left(20^{\circ} \mathrm{C}\right)$. Both antibodies were purchased from Jackson ImmunoResearch Europe Ltd. (Suffolk, UK). ß-Tubulin served as loading control. Finally, the immunocomplexes were made visible by ECL according to Haan and Behrmann and exposure to X-ray film (Fujifilm Europe GmbH, Düsseldorf, Germany). ${ }^{37}$

\section{Immunocytochemistry}

BT474, T-47D and MDA-MB2-231 cells were grown on microscope slides (SuperFrost ${ }^{\circledR}$ Plus, R. Langenbrinck, Emmendingen, Germany) in cell culture plates. At a confluence of $80 \%$, the medium was replaced by a medium containing citral, citrathal $\mathrm{R}$ or cyclovertal, each $50 \mu \mathrm{M}$. DMSO served as control. Incubation time was five hours, followed by a fixation of the cells in buffered formaldehyde (4\%, Carl Roth). Antigen retrieval was performed with $10 \mathrm{mM}$ sodium citrate buffer pH6. PBS containing $0.5 \%$ dry non-fat milk (AppliChem $\mathrm{GmbH}$ ) and $0.5 \%$ BSA (AppliChem $\mathrm{GmbH}$ ) was used as blocking solution. Primary antibody was diluted in blocking solution, and cells were incubated for two hours. The antibodies used Annexin V (sc32321, dilution 1:250) and PCNA (sc-56, dilution 1:7500) were both purchased from Santa Cruz Biotechnology, Inc. (Santa Cruz, USA). After washing, the slides were incubated with ImmPRESSTM HRP reagent peroxidase goat anti-mouse IgG (MP-7452, Vector Laboratories Inc., Burlingame, CA) for one hour. Staining was performed with DAB (SK-4100, DAB peroxidase substrate Kit, Vector Laboratories Inc., Burlingame, CA) and Haemalaun acidic Mayer (Waldeck, Münster, Germany). The Axioplan 2 microscope (Zeiss, Oberkochen, Germany) was used to analyse the images.

\section{Statistics}

All tests were performed in independent triplicates. Immunocytochemistry was performed as an independent duplicate. qRT-PCR analysis followed the delta-delta CT method described by Livak and Schmittgen calculated in Excel using GAPDH, ALAS1 and TBP as housekeeping genes. ${ }^{38,39}$ All statistical tests were performed in $\mathrm{R} 4.0 .2 .{ }^{40}$ The untreated BT474 cell line was defined as the expected control value (intercept). The influence of treatment on
RNA expression levels was investigated using a linear model with factor cell line (BT474, T47D, MDA-MB -231) and an interaction term of cell line and treatment (control, citral, citrathal R, cyclovertal, capsazepine, citral + capsazepine, citrathal R + capsazepine, cyclovertal + capsazepine).

\section{Results}

The effect of the poly-substance mixture, containing 20 $\mu \mathrm{M}$ of para-cymol, citral, hexylacetat, herbavert, dihydromyrcerol, limonen, citrathal $\mathrm{R}$ and cyclovertal, was investigated and results showed that the RNA expression of Ki67 was downregulated in all three cell lines. Consequently, further tests were performed to evaluate which of the eight substances was effective as a single agent. Citral, citrathal $\mathrm{R}$ and cyclovertal were revealed to be effective on all three cell lines as they downregulated the Ki67-RNA expression (Supplemental Figure 1). Thus, an MTT-assay was performed for these three specific substances to determine their corresponding IC50 values.

\section{MTT-Assay}

The determined dose effect curves are shown in Figure 1. All IC50 values were between $50 \mu \mathrm{M}$ and $75 \mu \mathrm{M}$, except for cyclovertal on the T-47D cells with $100 \mu \mathrm{M}$. Thus, it was decided to use a uniform concentration of $50 \mu \mathrm{M}$ for all odorant substances to treat all cell lines.

\section{Quantitative Expression Analysis in Effective Dosage Application Proliferation}

RNA expression of Ki67 was significantly reduced in T-47D and MDA-MB-231 cells after treatment with either $50 \mu \mathrm{M}$ citral, citrathal R or cyclovertal. In the BT474 cell line, the effects were not statistically significant (Figure 2). PCNAexpression was significantly reduced after treatment with 50 $\mu \mathrm{M}$ citral in all three cell lines (T-47D: $\mathrm{p}<0.001$ MDA-MB -231: $\mathrm{p}<0.001$, BT474: $\mathrm{p}<0.001)$ and following application of $50 \mu \mathrm{M}$ citrathal $\mathrm{R}$ in T-47D cells $(\mathrm{p}<0.001)$.

\section{Apoptosis}

p53-RNA expression was significantly higher in T-47D after treatment with $50 \mu \mathrm{M}$ citral $(\mathrm{p}<0.001)$. Further, RNA expression of the anti-apoptotic survivin shows significant reductions of expression levels in MDA-MB-231 $(\mathrm{p}<0.001)$ and T-47D $(\mathrm{p}<0.001)$ treated with $50 \mu \mathrm{M}$ citral, T-47D treated with $50 \mu \mathrm{M}$ citrathal $\mathrm{R}(\mathrm{p}<0.001)$ and MDA-MB-231 treated with $50 \mu \mathrm{M}$ cyclovertal $(\mathrm{p}<$ 


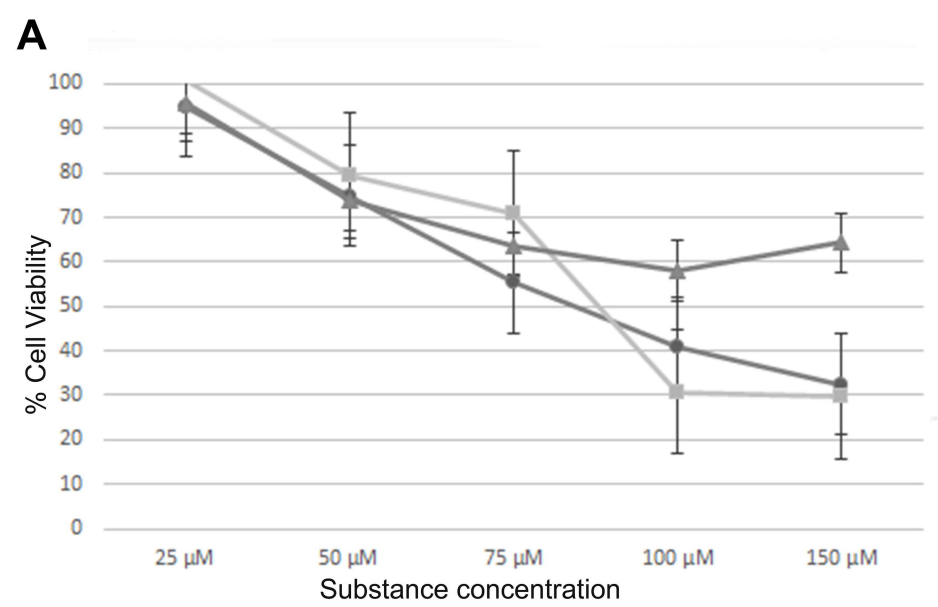

B

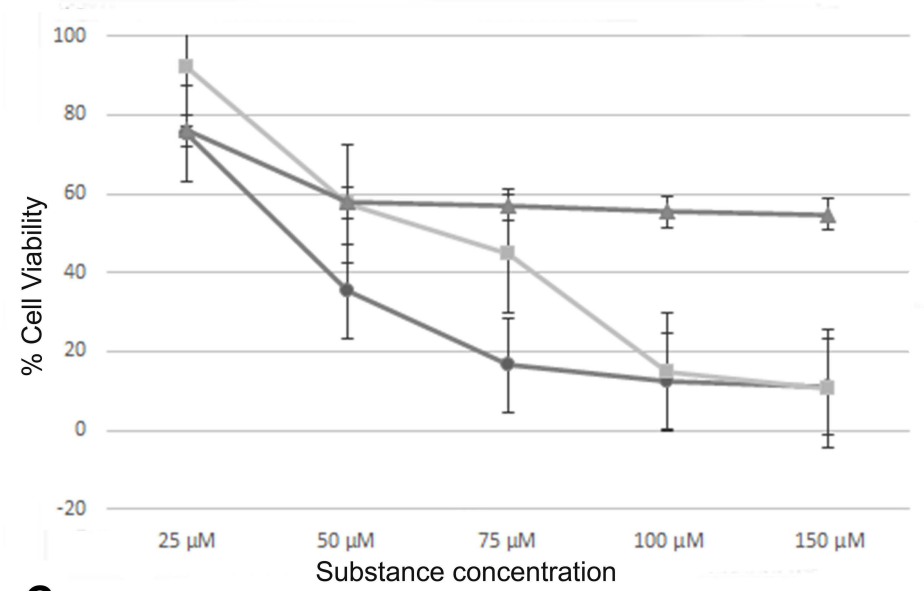

\section{C}

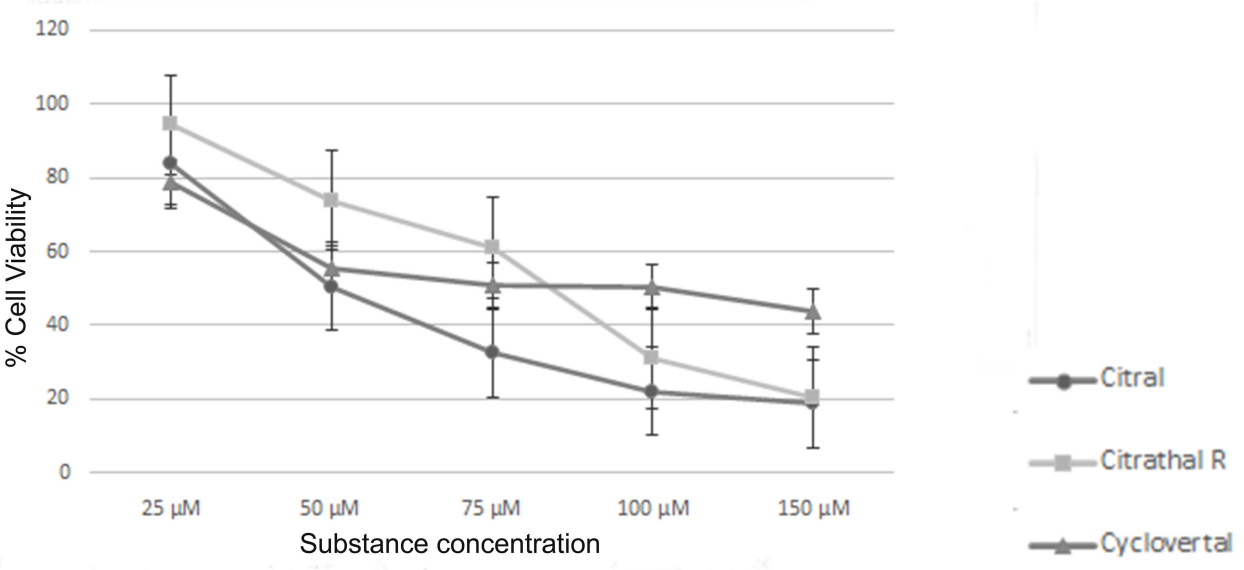

Figure I MTT-assay. (A) MTT-assay T-47D cells, (B) MTT-assay BT474 cells, (C) MTT-assay MDA-MB-23I cells.

0.001). In the BT474 cell line, the effects were not statistically significant (Figure 3). There were no significant regulations for the expression of SIRT1-RNA.

\section{Cell Cycle}

Most RNA expression regulations were shown for cyclin A2. In T-47D and MDA-MB-231 cell lines, decreased
RNA expression levels were observed after treatment with $50 \mu \mathrm{M}$ citral $(\mathrm{p}<0.001)$ (Figure 4). In MDA-MB -231, BT474 and T-47D cells, cyclin A2 expression was also substantially reduced after treatment with $50 \mu \mathrm{M}$ citrathal R (T-47D: $\mathrm{p}<0.001$, MDA-MB-231: $\mathrm{p}=$ 0.004, BT474: $\mathrm{p}=0.04)$. $50 \mu \mathrm{M}$ cyclovertal reduced cyclin A2 expression notably in MDA-MB-231 cells 
A

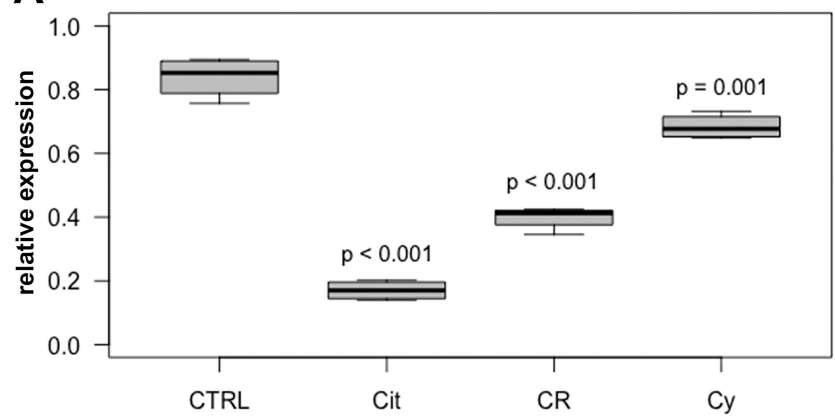

C

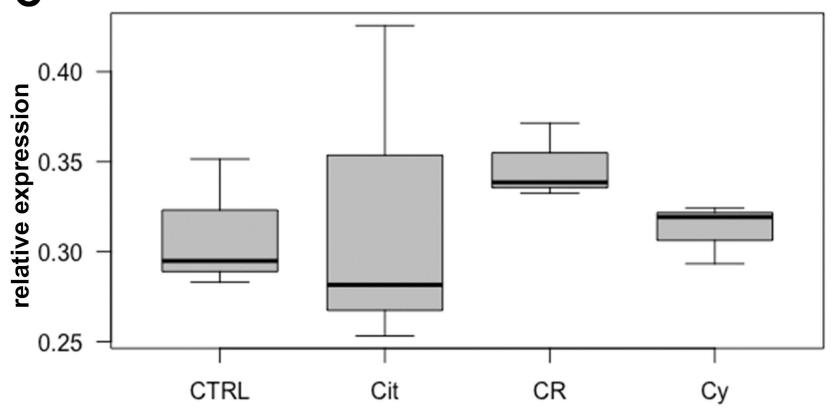

B

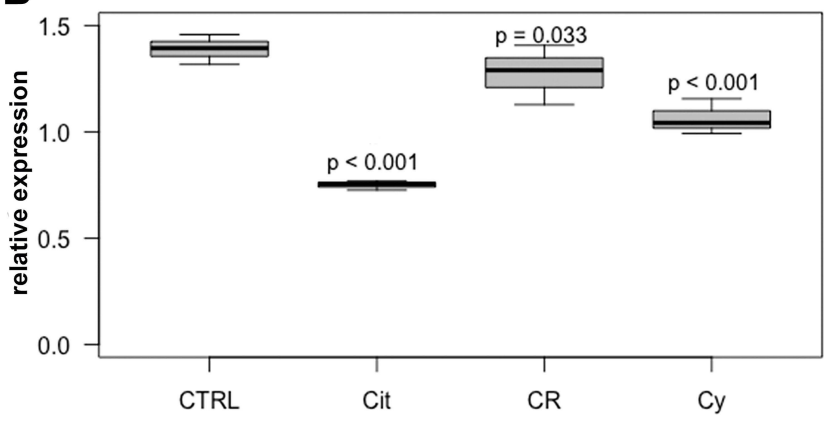

Figure 2 Ki67 in T-47D, MDA-MB-23I and BT474 cells. Relative intracellular expression of Ki67 RNA in T-47D cells (A), MDA-MB-23I cells (B) and BT474 cells (C) after

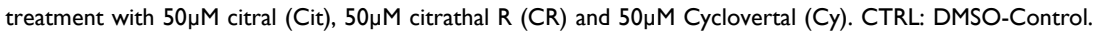
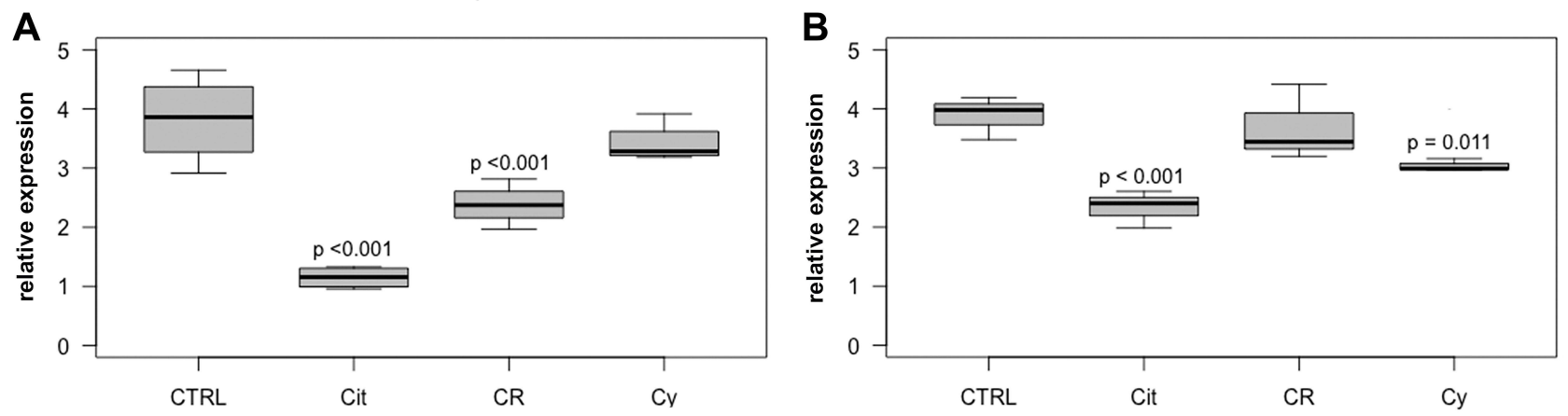

C

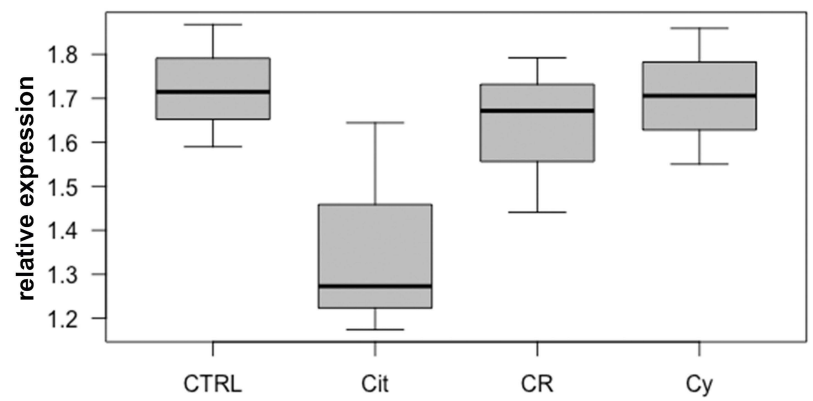

Figure 3 Survivin in T-47D, MDA-MB-23I and BT474 cells. Relative intracellular expression of survivin RNA in T-47D cells (A), MDA-MB-23I cells (B) and BT474 cells

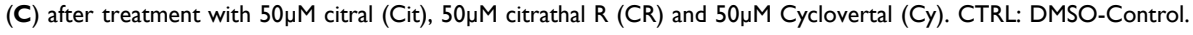

only $(\mathrm{p}<0.001)$. Cyclin D1 expression was reduced in all three cell lines after treatment with $50 \mu \mathrm{M}$ citral (T-47D: $\mathrm{p}<0.001$, MDA-MB-231: $\mathrm{p}=0.047$, BT474: $\mathrm{p}=0.017)$. RNA expression of cyclin E1 also shows a reduction in MDA-MB-231 cells after treatment with $50 \mu \mathrm{M}$ citral $(\mathrm{p}=0.033)$, and similarly in T-47D after treatment with $50 \mu \mathrm{M}$ citral $(\mathrm{p}<0.001)$ and after treatment with $50 \mu \mathrm{M}$ citrathal $\mathrm{R}(\mathrm{p}=0.014)$. 

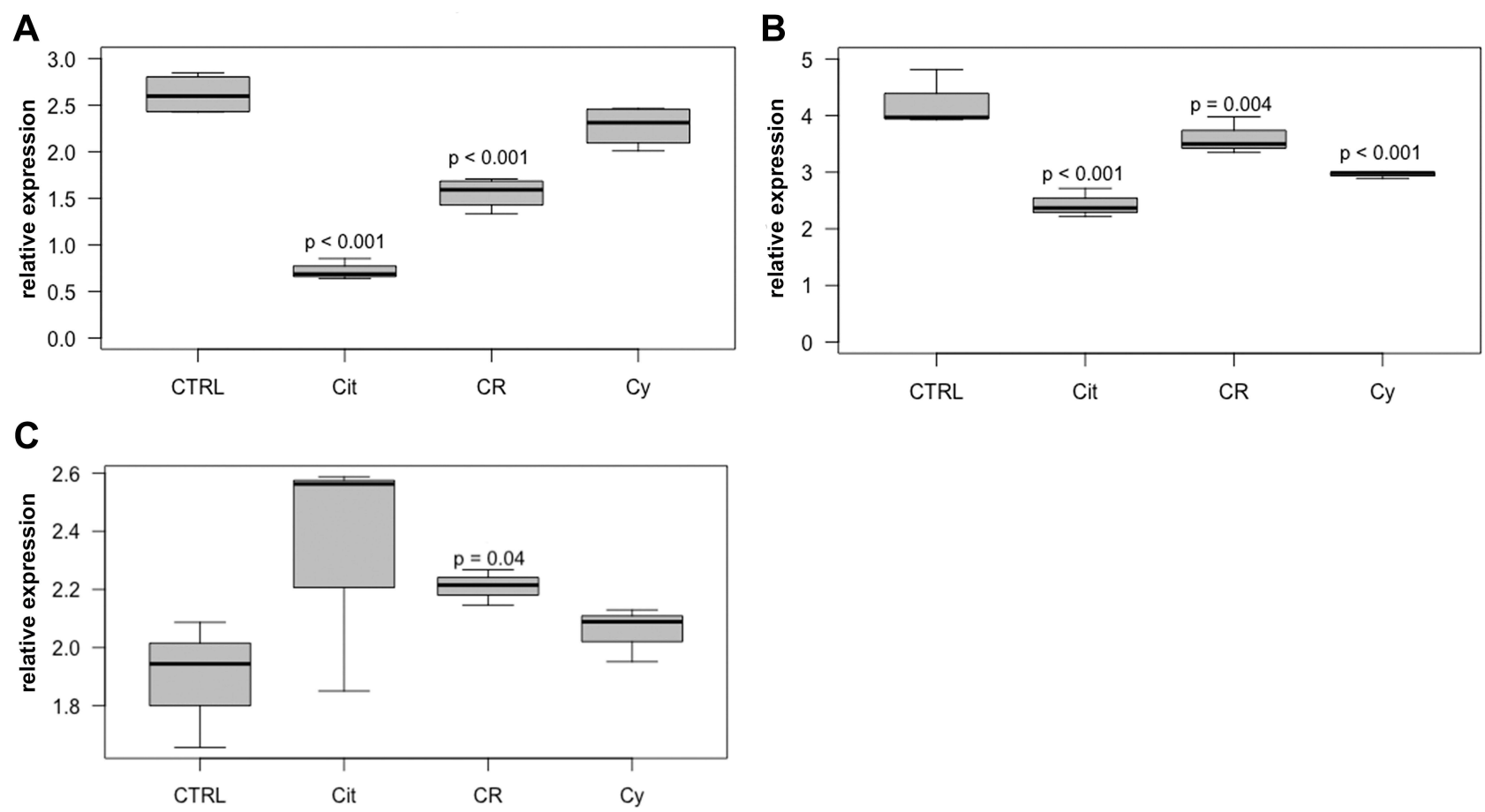

Figure 4 Cyclin A2 in T47-D, MDA-MB-23I and BT474 cells. Relative intracellular expression of cyclin A2 RNA in T-47D cells (A), MDA-MB-23I cells (B) and BT474 cells

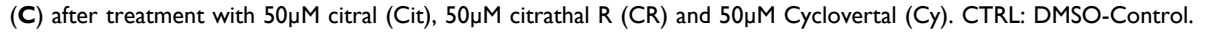

Moreover, the spindle assembly factor TPX2 showed significant reductions of RNA expression in all investigated cell lines after treatment with $50 \mu \mathrm{M}$ citral $(\mathrm{T}-47 \mathrm{D}$ : $\mathrm{p}<0.001$, MDA-MB-231: $\mathrm{p}<0.001$, BT474: $\mathrm{p}=0.035$ ), in T-47D cells after treatment with $50 \mu \mathrm{M}$ citrathal $\mathrm{R}(\mathrm{p}<$ $0.001)$ and in MDA-MB-231 $(\mathrm{p}=0.001)$ and T-47D $(\mathrm{p}=$ 0.002 ) cells after treatment with $50 \mu \mathrm{M}$ cyclovertal.

\section{Pathways}

ERK1, ERK2, p38-MAPK and STK24 were investigated to elucidate the possible impact of pathway regulations on RNA expression values. Significant reductions in RNA expression of ERK1 in MDA-MB-231 $(\mathrm{p}=0.034)$ and T-47D $(\mathrm{p}=$ 0.020 ) cells were observed following treatment with $50 \mu \mathrm{M}$ citral and in BT474 cells after treatment with $50 \mu \mathrm{M}$ cyclovertal $(p=0.045)$. ERK2-RNA expression was reduced after treatment with $50 \mu \mathrm{M}$ citral in MDA-MB-231 cells $(\mathrm{p}=$ 0.010) only (Supplemental Figure 2). In T-47D cells, the RNA expression of $\mathrm{p} 38$-MAPK was significantly reduced after treatment with $50 \mu \mathrm{M}$ citral $(\mathrm{p}=0.017)$. Finally, there were no significant changes of STK24 expression in any of the cell lines after the treatments (data not shown).

\section{Hormone Receptors}

RNA expression of progesterone and estrogen receptors were investigated in the hormone receptor-positive cell lines BT474 and T-47D. $50 \mu \mathrm{M}$ citral induced a significant reduction of progesterone receptor RNA expression in both cell lines (T-47D: $p<0.001$, BT474: $\mathrm{p}=0.017)$, in T-47D also $50 \mu \mathrm{M}$ citrathal $\mathrm{R}(\mathrm{p}<0.001)$. RNA expression of estrogen receptors in T-47D cells was significantly reduced after treatment with $50 \mu \mathrm{M}$ citral $(\mathrm{p}<$ 0.001) (Supplemental Figure 3).

\section{Co-Application of Capsazepine and Odorant Substances}

To investigate the role of TRPV1 in the functional processes of the analyzed odorant substances, capsazepine, a TRPV1 inhibitor, was co-applicated simultaneously with $50 \mu \mathrm{M}$ citral, citratal R and cyclovertal, respectively. Capsazepine itself turned out to be a highly potent toxic substance, which significantly reduced both proliferation (Ki67 $p<0.001$ and PCNA $\mathrm{p}<0.001$ RNA expression) and survivin $(\mathrm{p}<0.001)$ RNA expression levels in all cell lines. Furthermore, the application of capsazepine alone resulted in reduced RNA expressions of cyclins, particularly for the RNA expressions of cyclin D1, which were reduced in all three cell lines (T-47D: $p=0.002$, BT474 and MDA-MB-231: $p<0.001$ ).

Due to the analyses revealing that capsazepine itself is a potent substance, we investigated the tumor-suppressive effects of capsazepine plus odorant compared to capsazepine alone. Ki67 expression was significantly reduced in 
MDA-MB-231 when capsazepine was combined with citrathal $R(p=0.019)$ or cyclovertal $(p=0.022)$ was compared to capsazepine alone. The RNA expression of PCNA in MDA-MB-231 was significantly higher after treatment with a combination of citral and capsazepine than after capsazepine treatment alone $(p=0.045)$ (Figure 5A). The level of the anti-apoptotic survivin also increased significantly after treatment with the combination of citral and capsazepine compared to capsazepine alone in MDA-MB-231 cells $(p=0.003)$ (Figure 5B). Finally, the expression of cyclin A2 and cyclin D1 was significantly elevated with the combined treatment of citral and capsazepine compared to capsazepine-treatment alone in MDA-MB-231 cells $(p=0.024$ and $p=0.014)$ (Figure 5C and D).

In T-47D cells, the combination of any of the three odorant substances with capsazepine resulted in a significant reduction of p53 RNA expression compared to capsazepine alone (citral $\mathrm{p}=0.018$, citrathal $\mathrm{R} \mathrm{p}=$ 0.017, cyclovertal $\mathrm{p}=0.006$ ).

In BT474 cells, the cyclin A2 RNA expression was significantly reduced after co-application of both citrathal $\mathrm{R}$ and capsazepine $(\mathrm{p}=0.009)$ and cyclovertal and capsazepine $(\mathrm{p}=0.022)$, compared to capsazepine alone. Cyclin D1 RNA expression was significantly higher after co- applying with the combination of cyclovertal and capsazepine $(\mathrm{p}=0.043)$ compared to capsazepine alone. Finally, TPX2 RNA expression was significantly reduced after treatment with citrathal $\mathrm{R}$ and capsazepine compared to capsazepine alone $(p=0.029)$.

\section{Western Blot}

Western blots were performed to investigate alterations in protein levels after treatment with $50 \mu \mathrm{M}$ of each of the odorant substances, citral, citrathal $\mathrm{R}$ and cyclovertal alone and in combination with $50 \mu \mathrm{M}$ capsazepine.

PCNA was investigated for the proliferation rate and p53 for level of apoptosis. Further, TRPV1 expression was measured to determine the influence of capsazepine itself and the combinations of capsazepine with each of the odorant substances.

In T-47D cells, PCNA expression was reduced after the application of capsazepine and the odorant substances separately. The applications of citral or citral plus capsazepine were equally effective in reducing the PCNA expression. Citrathal $\mathrm{R}$ and cyclovertal, however, resulted in a higher efficacy in combination with capsazepine than they did individually. All approaches of T-47D showed an increased expression of p53 when the odorant substances were applied individually without
A
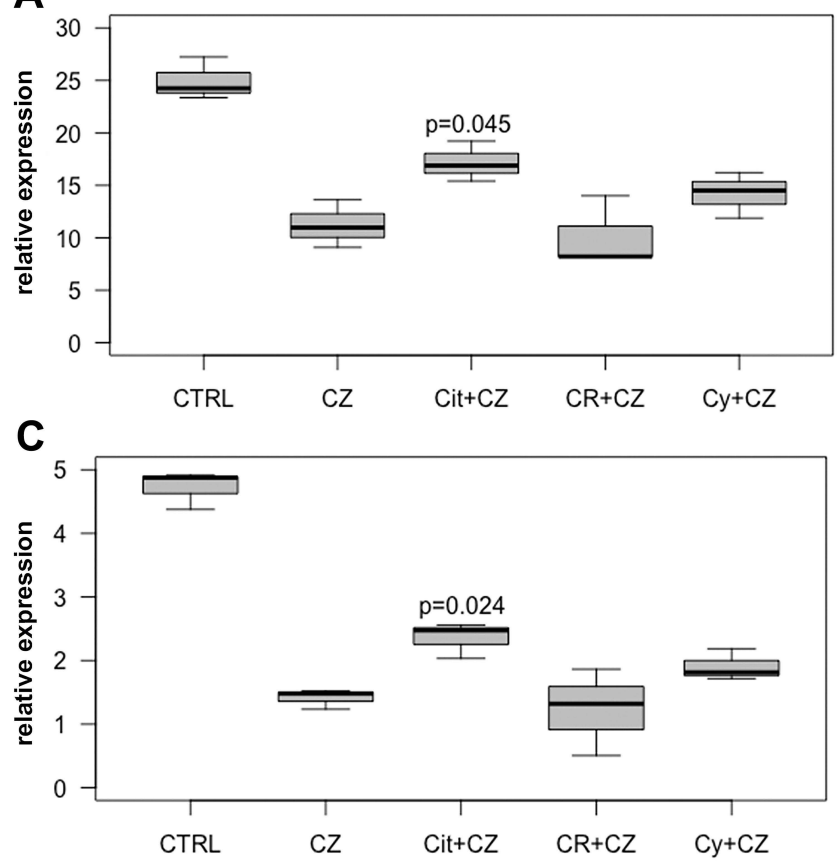

B
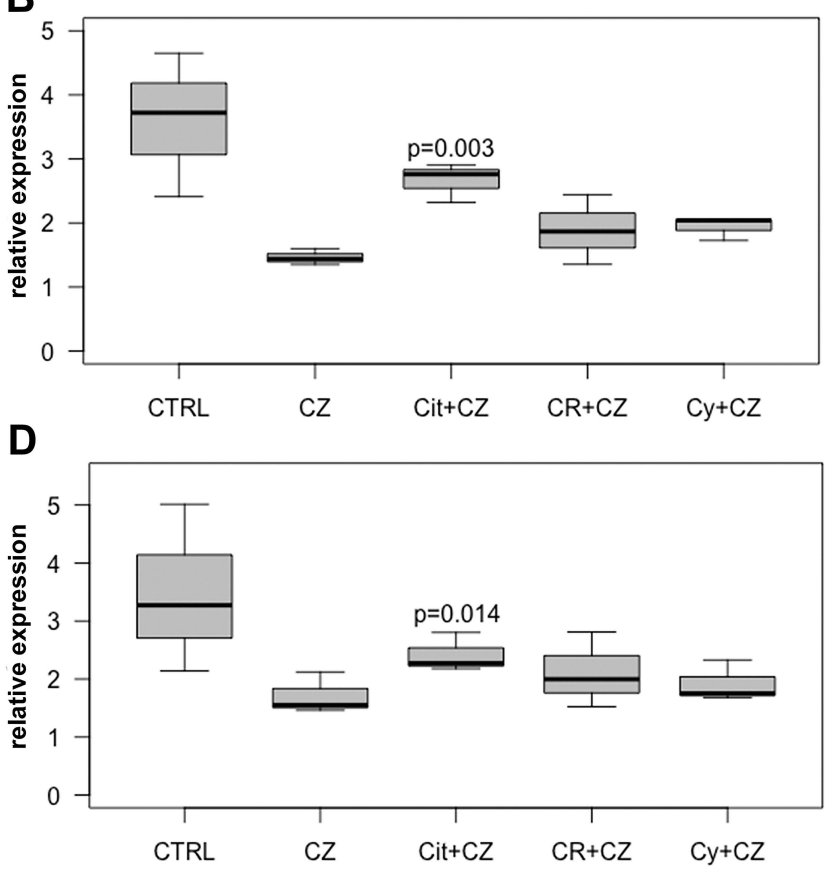

Figure 5 Effects of capsazepine. Relative intracellular expression of (A) PCNA, (B) survivin, (C) cyclin A2 and (D) cyclin DI RNA in MDA-MB-23I cells after treatment

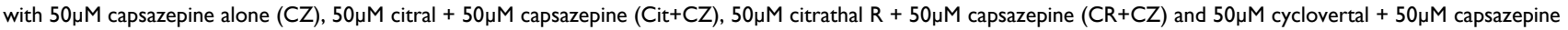
$(C y+C Z)$. 
capsazepine compared to the combined treatment. TRPV1 was no longer detectable after the application of capsazepine. These results for p53 and TRPV1 in T-47D were similar to the results in BT474 cells. The PCNA expression in BT474 was also reduced after the application of capsazepine and the odorant substances separately and showed no difference between citral alone and citral plus capsazepine. However, the reduction was more pronounced after concomitant use of citrathal $\mathrm{R}$ plus capsazepine and cyclovertal plus capsazepine compared to capsazepine alone. Although PCNA expression reduction occurred due to citral, citrathal $\mathrm{R}$ and cyclovertal treatment in MDA-MB 231 cells, capsazepine alone did not reduce PCNA expression, and the combination of citral and capsazepine led to no reduction of PCNA expression. Other in vitro models displayed a different effect. TRPV1 could be detected in all approaches except for the combination of citral and capsazepine. Figure 6 shows the results of the corresponding Western blots.

ERK1 and 2 were used as pathway markers, solely investigated after treatment with $50 \mu \mathrm{M}$ odorant substance and not following combined treatment with capsazepine. ERK1/2 expression was detected with reduced levels triggered by treatment with $50 \mu \mathrm{M}$ citral in T-47D cells and likewise with $50 \mu \mathrm{M}$ citrathal $\mathrm{R}$ in $\mathrm{T}-47 \mathrm{D}$ and MDA-MB -231 cells.

\section{Immunocytochemistry}

In addition to the characteristic antibody staining, immunocytochemistry revealed various substance-driven cytomorphological changes. Irrespective of the choice of the odorant substance, the nuclear-cytoplasmic ratio of T-47D and BT474 cells was found to be reduced, and the degree of nuclear condensation was observed to be at a remarkably higher level. MDA-MB-231 cells are normally oblong, spindle-shaped cells. Following treatment, cells had a round silhouette, lacking their characteristic spindle-shaped extensions, and the cell nuclei were deformed.

The PCNA staining of the nuclei resulted in a lower nuclear antigen count, especially in MDA-MB-231 cells. The induced staining effect of the outer cell membrane by apoptosis marker Annexin V was predominantly detected in BT474 cells after treatment with citrathal R (Figure 7).

\section{Discussion}

This study aims at investigating the potential effects of eight commonly used odorant substances (para-cymol, citral, hexylacetat, herbavert, dihydromyrcerol, limonen, citrathal $\mathrm{R}$ and cyclovertal) on the growth and vitality of three BC in vitro models: T474, T-47D, MDA-MB-231. Citral, citrathal $\mathrm{R}$ and cyclovertal showed antiproliferative effects.

As previous research described, citral appears to exert anti-proliferative and pro-apoptotic effects, and subsequently induces cell cycle arrest. ${ }^{41-43}$ The results of the present study confirm these previous findings on BC cell lines and the effects could be verified on RNA- (qRT-PCR) and protein level (Western blot, immunocytochemistry). The IC50 value of citral was $50 \mu \mathrm{M}$ for all cell lines investigated. This value corresponds to quantitative data of previous approaches. ${ }^{43,44}$ Chaouki et al investigated the effect of citral on apoptosis with an LDH-assay and concluded that concentrations of $200 \mu \mathrm{M}$ and lower lead rather to specific apoptotic effects than to necrosis or cell lysis. ${ }^{42}$ In the present study, the concentration of $50 \mu \mathrm{M}$, which was determined by the MTT assay, also lead to changes in

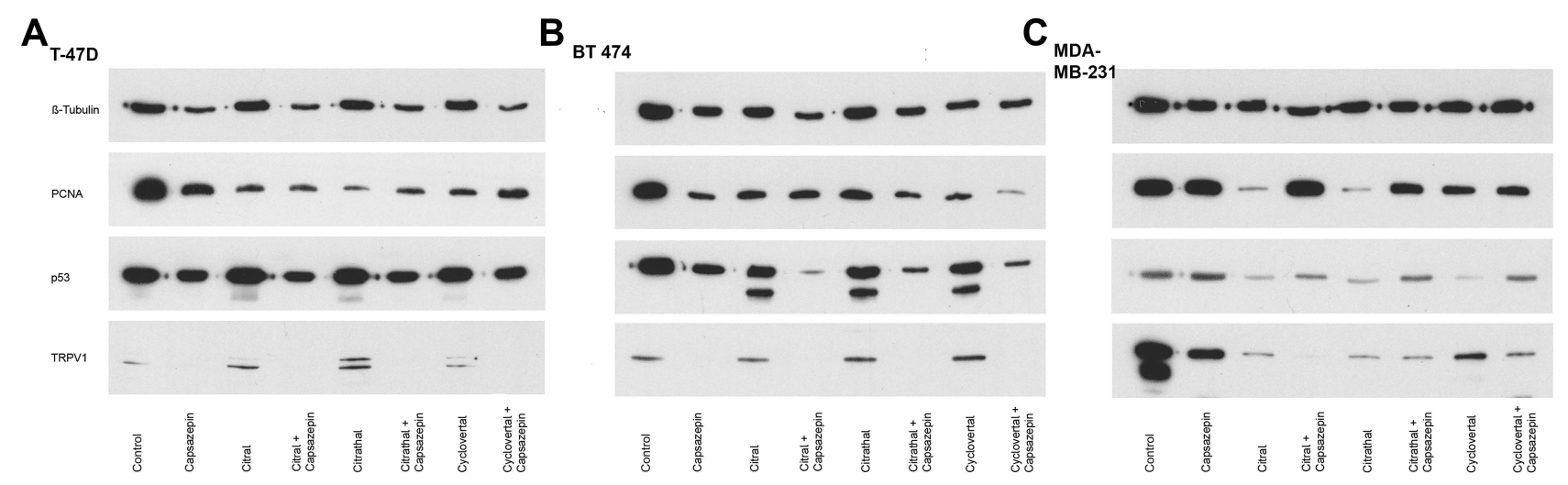

Figure 6 Western blots. Western Blot showing control, capsazepine alone, citral, citral + capsazepine, citrathal R, citrathal R + capsazepine, cyclovertal and cyclovertal + capsazepine. B-tubulin served as loading control in (A) T-47D, (B) BT474, (C) MDA-MB-23I. 

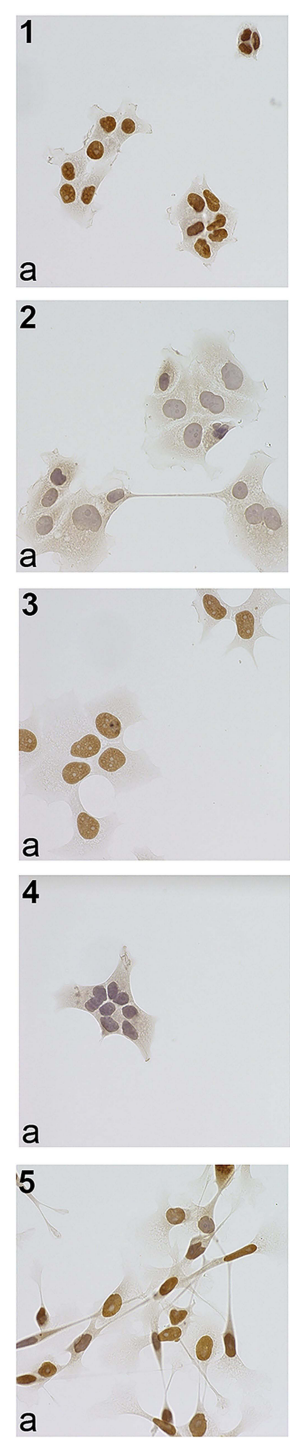

b
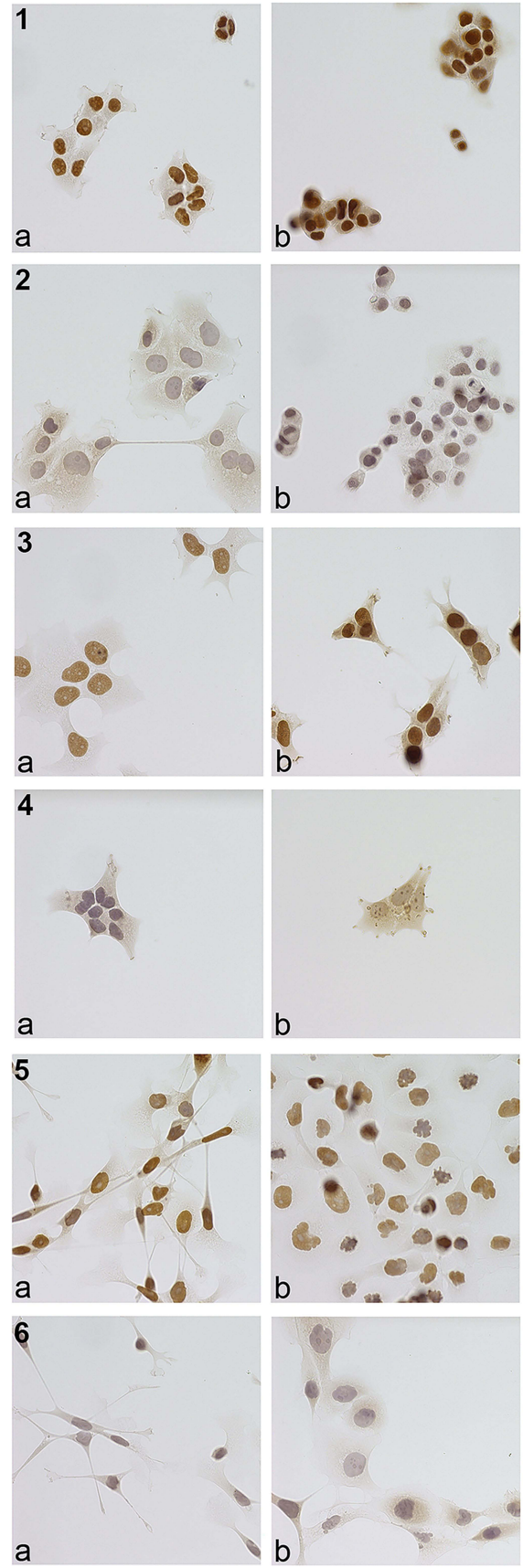

Figure 7 Immunocytochemistry. I: T-47D PCNA. Immunocytochemical staining of T47D cells with PCNA antibody (dilution I:7500, microscopic enlargement 400x). (a) control, (b) citral, (c) citrathal R, (d) cyclovertal. Compared to control reduced nuclear-cytoplasmic ratio and increased nuclear condensation. 2: T-47D Annexin V. Immunocytochemical staining of T47D cells with Annexin $V$ antibody (dilution I:250, microscopic enlargement 400x). (a) control, (b) citral, (c) citrathal R, (d) cyclovertal. Compared to control reduced nuclear-cytoplasmic ratio and increased nuclear condensation. Slightly increased staining of the outer cell membrane after citral treatment, more after citrathal R and cyclovertal, compared to the control. 3: BT474 PCNA. Immunocytochemical staining of BT474 cells with PCNA antibody (dilution I:7500, microscopic enlargement 400x). (a) control, (b) citral, (c) citrathal R, (d) cyclovertal. Compared to control reduced nuclear-cytoplasmic ratio and increased nuclear condensation. 4: BT474 Annexin V. Immunocytochemical staining of BT474 cells with Annexin V antibody (dilution I:250, microscopic enlargement 400x). (a) control, (b) citral, (c) citrathal R, (d) cyclovertal. Clearly increased staining of the outer cell membrane after citral, cylovertal and mostly after citrathal R treatment compared to the control. 5: MDA-MB-23I PCNA. Immunocytochemical staining of MDA-MB-23I cells with PCNA antibody (dilution I:7500, microscopic enlargement 400x). (a) control, (b) citral, (c) citrathal R, (d) cyclovertal. Compared to control reduced condensation and increased fragmentation of the nucleus and loss of spindle-shape after treatment mostly with citral and citrathal R, but also cyclovertal. Less intensive staining of the nuclei after treatment with citral, citrathal $\mathrm{R}$ and cyclovertal compared to the control. 6 : MDA-MB-23I Annexin V. Immunohistochemical staining of MDA-MB-23I cells with Annexin $V$ antibody (dilution I:250, microscopic enlargement 400x). (a) control, (b) citral, (c) citrathal R, (d) cyclovertal. Compared to control reduced condensation and increased fragmentation of the nucleus and loss of spindle-shape after treatment with citral, citrathal R and cyclovertal. Increased staining of the outer cell membrane after citral, citrathal R and mostly after cyclovertal treatment compared to the control. 
various apoptosis markers (Figures 3 and 4). Concerning apoptosis, Dudai et al reported the induction of caspase 3, a pro-apoptotic enzyme, by citral which also suggests the effect to be mediated by specific targets. ${ }^{45}$ Cell cycle arrests were described in $\mathrm{G} 2 / \mathrm{M}$ and $\mathrm{G} 0 / \mathrm{G} 1 .^{42,43}$ The downregulation of cyclin A2, D1 and E1 shown in this study indicates cell cycle arrests in G1 (cyclin D1), G1/S (cyclin E1) and S (cyclin A2). ${ }^{30,46,47}$ This emphasizes its potential role in $\mathrm{BC}$ therapy.

Similar anti-proliferative and pro-apoptotic effects were demonstrated for the odorant substances citrathal $\mathrm{R}$ and cyclovertal. No scientific literature is currently available regarding these substances and their antiproliferative and pro-apoptotic effects, and thus it is recommended they are introduced as new potent substances for growth inhibition in $\mathrm{BC}$ cell lines due to their demonstrated therapeutic potential. Since citrathal $\mathrm{R}$ is described to be the reaction product of citral and ethanol in the manufacturers' data sheet and consequently has structural similarity with citral, it can be assumed that their mode of action is similar. However, in the present study, the anti-proliferative effect of citral on $\mathrm{BC}$ cells appears to be TRPV1-mediated. Citrathal R additionally shows a TRPV1-independent effect. This TRPV1independent effect could also be shown for cyclovertal.

Further studies are needed to investigate the potential therapeutic effects of citrathal $\mathrm{R}$ and cyclovertal.

As mentioned in the introduction, the literature suggests that odorant substances transfer their effects via olfactory receptors, which are classified as G-protein coupled receptors. ${ }^{12}$ They bind to the receptors, activate them and transduce signals by activating different MAP kinases like ERK1, ERK2 and p38-MAPK. In this study, certain changes in the RNA expression levels were seen for ERK1/2 and p38-MAPK as described in the results. This indicates pathway regulations after treatment with odorant substances, but further studies are necessary for precise statements.

The determination of the relevant ectopic OR would be useful here. For this purpose, experiments with a knockout of the eligible receptors would be possible. In previous studies, the effect of citral on TRPV1 and other TRP channels has been shown. ${ }^{17,48}$ Based on this information, this study aimed to investigate the role of TRPV1 in the mechanisms of action of citral, citrathal $\mathrm{R}$ and cyclovertal. Beyond expectations, the TRPV1 inhibitor capsazepine, used in the experiments, showed an anti-proliferative and pro-apoptotic effect itself. ${ }^{49,50}$ Weber et al investigated the expression and functionality of TRPV1 in the triplenegative BC cell line SUM149PT. As in the current study, they applied a concentration of $50 \mu \mathrm{M}$ capsazepine. However, Weber et al did not describe an anti-proliferative and pro-apoptotic effect. ${ }^{23}$ Fazzari et al tested capsazepine on MDA-MB-231 cells and showed evidence for a reduction in cell viability after application of $50 \mu \mathrm{M}$ capsazepine, similar to the findings by Vercelli et al in MCF-7 BC cells. ${ }^{49,50}$ This could imply that the effect of capsazepine might be different between various cell lines. The present study demonstrated an anti-proliferative and pro-apoptotic effect of capsazepine on MDA-MB-231, T-47D and BT474 cells. The important role of TRP channels in cell calcium homeostasis, which itself is important for cell viability, could account for this effect. ${ }^{22}$ However, this study concluded that the combined application of capsazepine and odorant substance compared to capsazepine alone showed only limited regulations. Nonetheless, in MDA-MB-231 cells, we identified a significantly higher proliferation (elevated PCNA RNA expression), reduced apoptosis (elevated survivin RNA expression) and elevated cyclin A2 and D2 RNA expression levels following treatment with a combination of citral and capsazepine compared to capsazepine alone. This could be substantiated by the results on protein level by an elevated expression of the PCNA protein after combined treatment with citral and capsazepine compared to capsazepine treatment alone. The increased proliferation suggests that TRPV1 is essential for signal transduction in the mechanisms of action of citral. In T-47D, combinations of any of the three odorant substances with capsazepine resulted in lower p53 RNA expression levels than capsazepine alone, which indicates less apoptosis when inhibiting the TRPV1 channel. In contrast, in BT474 citrathal R and cyclovertal effect mechanisms are triggered and work, even though TRPV1 is inhibited. Ultimately, these data suggest that the signalling cascade connected to TRPV1 is needed for treatment with citral. No effects could be observed without TRPV1. For citrathal R and cyclovertal TRPV1 might play a signalling role. Still, effects are measurable in BT474 when inhibiting TRPV1. There might also be a difference among various cell lines, depending on their expression patterns.

Moreover, the data of the present study showed a reduced expression of estrogen and progesterone receptor RNA. This could result in reduced hormone receptor expression on the cell surface (Supplemental Figure 3). This might play an important role in successful BC 
therapy, as the estrogen receptors are one of the most important therapy targets. Reduced expression of these receptors might cause therapy failure of the endocrine treatment, like tamoxifen, for instance. ${ }^{51}$ The reduction in expression could also be potentially used therapeutically. The application of odorants shows an antiproliferative effect. In combination with the expression reduction of the hormone receptors, the effect could also be similar to SERD, such as fulvestrant. Additional studies are necessary to determine whether fragrances might also cause a reduction in the expression of estrogen receptors in vivo.

The exact mode of action of citral, as well as of citrathal $\mathrm{R}$ and cyclovertal, is not yet fully understood. There are descriptions of certain molecular effects, eg p53 induction and modulation of oxidative stress, as well as their effects on ALDH1A3 and ALDH in the context of drug resistance. ${ }^{41,44,52}$ However, none of them contains complete information about the mechanisms by which these effects are transduced from the cell surface.

Since the odorous substances bind to ORs, it is obvious that ectopic ORs are involved in signal transduction. The results of the current study suggest that the effect of citral is partly mediated by the TRPV1 receptor. Masjedi et al showed that the expression of different ectopic ORs varies in different BC cell lines. They suggested that the different expression of the ORs is related to the cell lines of the BC subtypes. ${ }^{20}$ The different endowment of ectopic ORs of BC subtypes could have a potential biomarker function and might have therapeutic potential, too. The three fragrances investigated showed a therapeutically interesting effect. It is possible that there are other substances in the field of fragrances with similar or better therapeutically useful effects. Future studies will have to show whether the associated possible therapeutic potential of fragrances can be used. The mode of application, in the form of solutions and creams, is also still unclear.

As this study is limited to in-vitro investigations, equivalent in-vivo effects of the odorant substances can only be assumed. In particular, questions like the possibility of odorant application and the achievement of sufficient doses of breast tissue in vivo have not yet been answered.

\section{Conclusion}

This study shows that the odorant substances citral, citrathal $\mathrm{R}$ and cyclovertal have anti-proliferative, proapoptotic and cell cycle arresting effects on the three BC cell lines T-47D, BT474 and MDA-MB-231.
This effect offers a potential therapeutic option for the future therapy of BC. Moreover, an effect on the expression of hormone receptor RNA expression levels was shown, which might represent an interesting target for readjustment following unsuccessful therapy. Finally, this study suggests that TRPV1 is a critical component of an effective citral-based treatment to evolve its antiproliferative effect on BC cells. For citrathal $\mathrm{R}$ and cyclovertal signaling, TRPV1 might play a functional role; however, the crucial mechanism seems to work independently of TRPV1 and has not yet been described. Further studies are required to identify and qualify this mechanism and the in vivo effect of the odorant substances.

\section{Abbreviations}

$\mathrm{BC}$, breast cancer; ERK1/2, extracellular signal-regulated kinases 1/2; GPCRs, G protein-coupled receptors; ORs, Olfactory receptors; p38 MAPK, p38 mitogen-activated kinase; PCNA, Proliferating Cell Nuclear Antigen; RNA, ribonucleic acid; STK24, serine/threonine kinase 24; TPX2, targeting protein for Xklp2; TRP, transient receptor potential channels; WHO, World Health Organization.

\section{Data Sharing Statement}

The datasets analysed during the current study are available from the corresponding authors on reasonable request.

\section{Acknowledgments}

We express our special thanks to Mrs. Claudia Nöthling for her excellent work as a medical-technical assistant.

\section{Author Contributions}

All authors made a significant contribution to the work reported, whether that is in the conception, study design, execution, acquisition of data, analysis and interpretation, or in all these areas; took part in drafting, revising or critically reviewing the article; gave final approval of the version to be published; have agreed on the journal to which the article has been submitted; and agree to be accountable for all aspects of the work.

\section{Funding}

This research did not receive any specific grant from any funding agency in the public, commercial or not-for-profit sector. 


\section{Disclosure}

The authors declare that they have no known competing financial interests or personal relationships that could have appeared to influence the work reported in this paper.

\section{References}

1. Bray F, Ferlay J, Soerjomataram I, Siegel RL, Torre LA, Jemal A. Global cancer statistics 2018: GLOBOCAN estimates of incidence and mortality worldwide for 36 cancers in 185 countries. CA Cancer J Clin. 2018;68(6):394-424. doi:10.3322/caac.21492

2. Lakhani SR; International Agency for Research on Cancer, Weltgesundheitsorganisation, editors. WHO Classification of Tumours of the Breast: Views of a Working Group That Convened for a Consensus and Editorial Meeting at the International Agency for Research on Cancer (IARC), Lyon, September 1-3, 2011. 4ed. Internat. Agency for Research on Cancer; 2012.

3. Harbeck N, Gnant M. Breast cancer. Lancet Lond Engl. 2017;389 (10074):1134-1150. doi:10.1016/S0140-6736(16)31891-8

4. Gianni L, Dafni U, Gelber RD, et al. Treatment with trastuzumab for 1 year after adjuvant chemotherapy in patients with HER2-positive early breast cancer: a 4-year follow-up of a randomised controlled trial. Lancet Oncol. 2011;12(3):236-244. doi:10.1016/S14702045(11)70033-X

5. Greenlee H, DuPont-Reyes MJ, Balneaves LG, et al. Clinical practice guidelines on the evidence-based use of integrative therapies during and after breast cancer treatment: integrative therapies during and after breast cancer treatment. CA Cancer J Clin. 2017;67(3):194-232. doi:10.3322/caac. 21397

6. Lopes CM, Dourado A, Oliveira R. Phytotherapy and nutritional supplements on breast cancer. BioMed Res Int. 2017;2017:1-42. doi:10.1155/2017/7207983

7. Parmentier M, Libert F, Schurmans S, et al. Expression of members of the putative olfactory receptor gene family in mammalian germ cells. Nature. 1992;355(6359):453-455. doi:10.1038/355453a0

8. Flegel C, Manteniotis S, Osthold S, Hatt H, Gisselmann G. Expression profile of ectopic olfactory receptors determined by deep sequencing. PLoS One. 2013;8(2):e55368. doi:10.1371/journal. pone. 0055368

9. Spehr M, Gisselmann G, Poplawski A. Identification of a testicular odorant receptor mediating human sperm chemotaxis. Science. 2003;299(5615):2054-2058. doi:10.1126/science.1080376

10. Busse D, Kudella P, Grüning N-M, et al. A synthetic sandalwood odorant induces wound-healing processes in human keratinocytes via the olfactory receptor OR2AT4. J Invest Dermatol. 2014;134 (11):2823-2832. doi:10.1038/jid.2014.273

11. Neuhaus EM, Zhang W, Gelis L, Deng Y, Noldus J, Hatt H. Activation of an olfactory receptor inhibits proliferation of prostate cancer cells. J Biol Chem. 2009;284(24):16218-16225. doi:10.1074/ jbc.M109.012096

12. Maßberg D, Hatt H. Human olfactory receptors: novel cellular functions outside of the nose. Physiol Rev. 2018;98(3):1739-1763. doi:10.1152/physrev.00013.2017

13. Spehr J, Gelis L, Osterloh M, et al. G protein-coupled receptor signaling via src kinase induces endogenous human transient receptor potential vanilloid type 6 (TRPV6) channel activation. J Biol Chem. 2011;286(15):13184-13192. doi:10.1074/jbc.M110.183525

14. Gelis L, Jovancevic N, Veitinger S, et al. Functional characterization of the odorant receptor 51E2 in human melanocytes. $J$ Biol Chem. 2016;291(34):17772-17786. doi:10.1074/jbc.M116.734517

15. Manteniotis S, Wojcik S, Brauhoff P, et al. Functional characterization of the ectopically expressed olfactory receptor 2AT4 in human myelogenous leukemia. Cell Death Discov. 2016;2(1). doi:10.1038/ cddiscovery. 2015.70
16. Montell C. The TRP superfamily of cation channels. Sci STKE Signal Transduct Knowl Environ. 2005;2005(272):re3. doi:10.1126/stke.27 22005re3

17. Stotz SC, Vriens J, Martyn D, Clardy J, Clapham DE. Citral sensing by TRANSient receptor potential channels in Dorsal Root Ganglion neurons. PLoS One. 2008;3(5):e2082. doi:10.1371/journal.pone.00 02082

18. Liebmann C. G protein-coupled receptors and their signaling pathways: classical therapeutical targets susceptible to novel therapeutic concepts. Curr Pharm Des. 2004;10(16):1937-1958. doi:10.2174/ 1381612043384367

19. Weber L, Maßberg D, Becker C, et al. Olfactory receptors as biomarkers in human breast carcinoma tissues. Front Oncol. 2018;8. doi: $10.3389 /$ fonc. 2018.00033

20. Masjedi S, Zwiebel LJ, Giorgio TD. Olfactory receptor gene abundance in invasive breast carcinoma. Sci Rep. 2019;9(1):13736. doi:10.1038/s41598-019-50085-4

21. Dhennin-Duthille I, Gautier M, Faouzi M, et al. High expression of transient receptor potential channels in human breast cancer epithelial cells and tissues: correlation with pathological parameters. Cell Physiol Biochem. 2011;28(5):813-822. doi:10.1159/000335795

22. Guilbert A, Gautier M, Dhennin-Duthille I, Haren N, Sevestre H, Ouadid-Ahidouch H. Evidence that TRPM7 is required for breast cancer cell proliferation. Am J Physiol Cell Physiol. 2009;297(3): C493-C502. doi:10.1152/ajpcell.00624.2008

23. Weber LV, Al-Refae K, Wölk G, et al. Expression and functionality of TRPV1 in breast cancer cells. Breast Cancer Targets Ther. 2016;8:243-252. doi:10.2147/BCTT.S121610

24. Scholzen T, Gerdes J. The Ki-67 protein: from the known and the unknown. J Cell Physiol. 2000;182(3):311-322. doi:10.1002/(SICI) 1097-4652(200003)182:3<311::AID-JCP1>3.0.CO;2-9

25. Juríková M, Danihel L', Polák Š, Varga I. Ki67, PCNA, and MCM proteins: markers of proliferation in the diagnosis of breast cancer. Acta Histochem. 2016;118(5):544-552. doi:10.1016/j.acthis.2016.05.002

26. Green DR, Kroemer G. Cytoplasmic functions of the tumour suppressor p53. Nature. 2009;458(7242):1127-1130. doi:10.1038/nature07986

27. Vaziri H, Dessain SK, Ng Eaton E, et al. hSIR2(SIRT1) functions as an NAD-dependent p53 deacetylase. Cell. 2001;107(2):149-159. doi:10.1016/s0092-8674(01)00527-x

28. Mita AC, Mita MM, Nawrocki ST, Giles FJ. Survivin: key regulator of mitosis and apoptosis and novel target for cancer therapeutics. Clin Cancer Res. 2008;14(16):5000-5005. doi:10.1158/1078-0432.CCR08-0746

29. Brumatti G, Sheridan C, Martin SJ. Expression and purification of recombinant annexin $\mathrm{V}$ for the detection of membrane alterations on apoptotic cells. Methods. 2008;44(3):235-240. doi:10.1016/j.ymeth. 2007.11.010

30. Zhong Z, Yeow W-S, Zou C, et al. Cyclin D1/Cyclin-dependent Kinase 4 interacts with Filamin $\mathrm{A}$ and affects the migration and invasion potential of breast cancer cells. Cancer Res. 2010;70 (5):2105-2114. doi:10.1158/0008-5472.CAN-08-1108

31. Aguirre-Portoles C, Bird AW, Hyman A, Canamero M, Perez de Castro I, Malumbres M. Tpx2 controls spindle integrity, genome stability, and tumor development. Cancer Res. 2012;72(6):15 18-1528. doi:10.1158/0008-5472.CAN-11-1971

32. McCubrey JA, Steelman LS, Chappell WH, et al. Roles of the Raf/ MEK/ERK pathway in cell growth, malignant transformation and drug resistance. Biochim Biophys Acta BBA Mol Cell Res. 2007;1773(8):1263-1284. doi:10.1016/j.bbamcr.2006.10.001

33. Cuenda A, Rousseau S. p38 MAP-Kinases pathway regulation, function and role in human diseases. Biochim Biophys Acta BBA Mol Cell Res. 2007;1773(8):1358-1375. doi:10.1016/j.bbamcr.2007.03.010

34. O'Neill E, Rushworth L, Baccarini M, Kolch W. Role of the Kinase MST2 in suppression of apoptosis by the proto-oncogene product Raf-1. Science. 2004;306(5705):2267-2270. doi:10.1126/science.11 03233 
35. Madsen CD, Hooper S, Tozluoglu M, et al. STRIPAK components determine mode of cancer cell migration and metastasis. Nat Cell Biol. 2014;17(1):68-80. doi:10.1038/ncb3083

36. Schägger $H$, von Jagow G. Tricine-sodium dodecyl sulfate-polyacrylamide gel electrophoresis for the separation of proteins in the range from 1 to $100 \mathrm{kDa}$. Anal Biochem. 1987;166(2): 368-379. doi:10.1016/0003-2697(87)90587-2

37. Haan C, Behrmann I. A cost effective non-commercial ECL-solution for Western blot detections yielding strong signals and low background. J Immunol Methods. 2007;318(1-2):11-19. doi:10.10 16/j.jim.2006.07.027

38. Livak KJ, Schmittgen TD. Analysis of relative gene expression data using real-time quantitative PCR and the 2(-Delta Delta C(T)) method. Methods San Diego Calif. 2001;25(4):402-408. doi:10.10 06/meth.2001.1262

39. Microsoft Corporation. Microsoft Excel; 2017.

40. R Foundation for Statistical Computing. R Core Team. R: a language and environment for statistical computing; 2020. Available from: https://www.R-project.org/. Accessed November 9, 2020.

41. Nigjeh SE, Yeap SK, Nordin N, Kamalideghan B, Ky H, Rosli R. Citral induced apoptosis in MDA-MB-231 spheroid cells. BMC Complement Altern Med. 2018;18(1). doi:10.1186/s12906-0182115-y

42. Chaouki W, Leger DY, Liagre B, Beneytout J-L, Hmamouchi M. Citral inhibits cell proliferation and induces apoptosis and cell cycle arrest in MCF-7 cells. Fundam Clin Pharmacol. 2009;23(5):549-556. doi:10.1111/j.1472-8206.2009.00738.x

43. Patel PB, Thakkar VR, Patel JS. Cellular effect of curcumin and citral combination on breast cancer cells: induction of apoptosis and cell cycle arrest. J Breast Cancer. 2015;18(3):225. doi:10.4048/jbc. 2015.18.3.225
44. Kapur A, Felder M, Fass L, et al. Modulation of oxidative stress and subsequent induction of apoptosis and endoplasmic reticulum stress allows citral to decrease cancer cell proliferation. Sci Rep. 2016;6(1). doi:10.1038/srep27530

45. Dudai N, Weinstein Y, Krup M, Rabinski T, Ofir R. Citral is a new inducer of Caspase-3 in tumor cell lines. Planta Med. 2005;71 (5):484-488. doi:10.1055/s-2005-864146

46. Sauer K, Lehner CF. The role of cyclin E in the regulation of entry into S phase. Prog Cell Cycle Res. 1995;1:125-139.

47. Pagano M, Pepperkok R, Verde F, Ansorge W, Draetta G. Cyclin A is required at two points in the human cell cycle. EMBO J. 1992;11 (3):961-971. doi:10.1002/j.1460-2075.1992.tb05135.x

48. Ohtsubo S, Fujita T, Matsushita A, Kumamoto E. Inhibition of the compound action potentials of frog sciatic nerves by aroma oil compounds having various chemical structures. Pharmacol Res Perspect. 2015;3(2):e00127. doi:10.1002/prp2.127

49. Fazzari J, Lin H, Murphy C, Ungard R, Singh G. Inhibitors of glutamate release from breast cancer cells; new targets for cancer-induced bone-pain. Sci Rep. 2015;5(1). doi:10.1038/ srep08380

50. Vercelli C, Barbero R, Cuniberti B, et al. Transient receptor potential vanilloid 1 expression and functionality in MCF-7 cells: a preliminary investigation. $J$ Breast Cancer. 2014;17(4):332. doi:10.4048/jbc.2014.17.4.332

51. Haque M, Desai KV. Pathways to endocrine therapy resistance in breast cancer. Front Endocrinol. 2019;10. doi:10.3389/fendo.2019. 00573

52. Thomas ML, de Antueno R, Coyle KM, et al. Citral reduces breast tumor growth by inhibiting the cancer stem cell marker ALDH1A3. Mol Oncol. 2016;10(9):1485-1496. doi:10.1016/j.molonc.2016.08. 004

\section{Publish your work in this journal}

Breast Cancer - Targets and Therapy is an international, peer-reviewed open access journal focusing on breast cancer research, identification of therapeutic targets and the optimal use of preventative and integrated treatment interventions to achieve improved outcomes, enhanced survival and quality of life for the cancer patient.
The manuscript management system is completely online and includes a very quick and fair peer-review system, which is all easy to use. Visit http://www.dovepress.com/testimonials.php to read real quotes from published authors. 